\title{
Risk factors of postoperative pulmonary complications after minimally invasive anatomic resection for lung cancer
}

This article was published in the following Dove Medical Press journal: Therapeutics and Clinical Risk Management

\author{
Rong Yang' \\ Yihe $\mathrm{Wu}^{2,3}$ \\ Linpeng Yao' \\ Jinming $X \mathrm{u}^{2}$ \\ Siying Zhang' \\ Chengli $\mathrm{Du}^{2}$ \\ Feng Chen' \\ 'Department of Radiology, The \\ First Affiliated Hospital, College \\ of Medicine, Zhejiang University, \\ Hangzhou 310003, Zhejiang Province, \\ China; ${ }^{2}$ Department of Thoracic \\ Surgery, The First Affiliated Hospital, \\ College of Medicine, Zhejiang \\ University, Hangzhou 310003, Zhejiang \\ Province, China; ${ }^{3}$ Department of \\ Thoracic Surgery, The First Division \\ Hospital of Xinjiang Corps, Aksu \\ City 843000, Xinjiang Autonomous \\ Region, China
}

Purpose: This study investigated the perioperative risk factors of postoperative pulmonary complications (PPCs) after minimally invasive anatomic resection for lung cancer.

Patients and methods: We retrospectively reviewed the data from medical records of 729 lung cancer patients undergoing minimally invasive anatomic lung resections between January 2017 and December 2017. Univariate and binary logistic regression analyses were performed to select the independent risk factors for PPCs during the patient's postoperative hospitalization after surgery.

Results: The incidence of PPCs was $24.8 \%(n=181 / 729)$. No patient died during the period of hospitalization. Logistic regression analysis revealed that body mass index (BMI) $\geq 24.0 \mathrm{~kg} / \mathrm{m}^{2}$ (vs $<24.0 \mathrm{~kg} / \mathrm{m}^{2}$ : OR $1.514,95 \%$ CI $1.057-2.167, P=0.024$ ), single segmentectomy (vs single lobectomy: OR 2.115, 95\% CI 1.150-3.891, $P=0.016$ ), bilobectomy or combined lobectomy and segmentectomy (vs single lobectomy: OR 2.731, 95\% CI 1.013-7.361, $P=0.047$ ), and right lung lobe surgery (vs left lung lobe surgery: OR 1.519, 95\% CI 1.046-2.205, $P=0.028$ ) were independent risk factors for PPCs in lung cancer patients who received minimally invasive anatomic lung resections.

Conclusion: Individual factors such as BMI $\geq 24.0 \mathrm{~kg} / \mathrm{m}^{2}$, single segmentectomy, bilobectomy or combined lobectomy and segmentectomy, and right lung lobe surgery were independent risk factors of PPCs, which should be helpful for risk stratification, patient counseling, and perioperative care for lung cancer patients.

Keywords: lung cancer, minimally invasive lung resection, postoperative pneumonia, postoperative pulmonary complications, risk factors

\section{Introduction}

Lung cancer is the leading cause of cancer death worldwide for both genders, and anatomic lung resection is widely considered the optimal therapy for early-stage lung cancer. ${ }^{1}$ Video-assisted thoracoscopic surgery or robotic-assisted thoracoscopic surgery is being increasingly performed for early-stage lung cancer instead of open thoracotomy because of its minimally invasive nature. ${ }^{2}$ Despite the improvement in surgical techniques, postoperative pulmonary complications (PPCs) still occur in $12 \%-40 \%$ of patients after surgical lung resection, and increase hospital mortality, postoperative length of stay (PLOS), and total hospital care costs. ${ }^{1}$ Several previous studies have suggested that the patient's age, gender, and body mass index (BMI), as well as smoking and COPD, are risk factors of PPCs after lung resection. ${ }^{3-5}$ However, data regarding the risk factors of PPCs after lung resection are still limited and often from small sample sizes. ${ }^{3-6}$ Moreover, there are too many perioperative associated
Department of Radiology, The First Affiliated Hospital, College of Medicine, Zhejiang University, 79 Qingchun Road, Hangzhou 310003, China

Tel +86 57l 87236587

Email chenfenghz@zju.edu.cn 
factors for PPCs after lung resection, many of which are still are not being studied and understood. Therefore, further research is needed to address this knowledge gap.

In this study, we retrospectively reviewed patients with lung cancer undergoing minimally invasive anatomic resection and compared the perioperative factors between patients with PPCs and patients with no PPCs. The study aimed to identify perioperative risk factors for the development of PPCs after minimally invasive anatomic resection for lung cancer. Knowledge about these factors might help to identify patients at elevated risk for the development of PPCs and, therefore, contribute to a decrease in such complications.

\section{Patients and methods}

The Medical Ethics Committee of the First Affiliated Hospital, College of Medicine, Zhejiang University, Hangzhou, China, approved the study. Because the data were recorded retrospectively and without any specific intervention, the Medical Ethics Committee agreed to waive the need for informed consent. Data were deidentified to protect the privacy and maintain confidentiality of patient information. It was conducted in accordance with the 1964 Declaration of Helsinki and its later amendments covering patient data confidentiality.

\section{Study population}

We retrospectively collected the records of consecutive lung cancer patients who had undergone anatomic lung resections between January 2017 and December 2017, at the First Affiliated Hospital, College of Medicine, Zhejiang University. The inclusion criteria were 1) patients aged over 18 years, 2) patients who had undergone minimally invasive anatomic lung resections under general anesthesia with double-lumen intubation, and 3) pathological confirmation of lung cancer. Minimally invasive anatomic lung resection was defined as lobectomy or segmentectomy under video-assisted thoracoscopic surgery or robotic-assisted thoracoscopic surgery. Exclusion criteria were patients who had undergone 1 ) open surgery and 2) conversion to thoracotomy. A total of 922 patient records were evaluated, but 193 were excluded because of open surgery ( $n=162)$, conversion to thoracotomy $(n=27)$, or incomplete data $(n=4)$. Finally, 729 valid cases were included (Figure 1).

Detailed patient data of the whole cohort are provided in Tables 1 and 2. A low-tidal-volume ventilation strategy was implemented during single lung ventilation. All patients received prophylactic first/second-generation cephalosporins until removal of chest tubes. However, if the patient was diagnosed with a postoperative infection, the antibiotic was adjusted to sulbactam, ampicillin, and ciprofloxacin. If there was no risk of aspiration, the patients were started on oral feedings in the sixth to eighth postoperative hour.

\section{Variables and outcomes of interest}

The variables comprised preoperative, intraoperative, and postoperative factors, extracted from medical records,

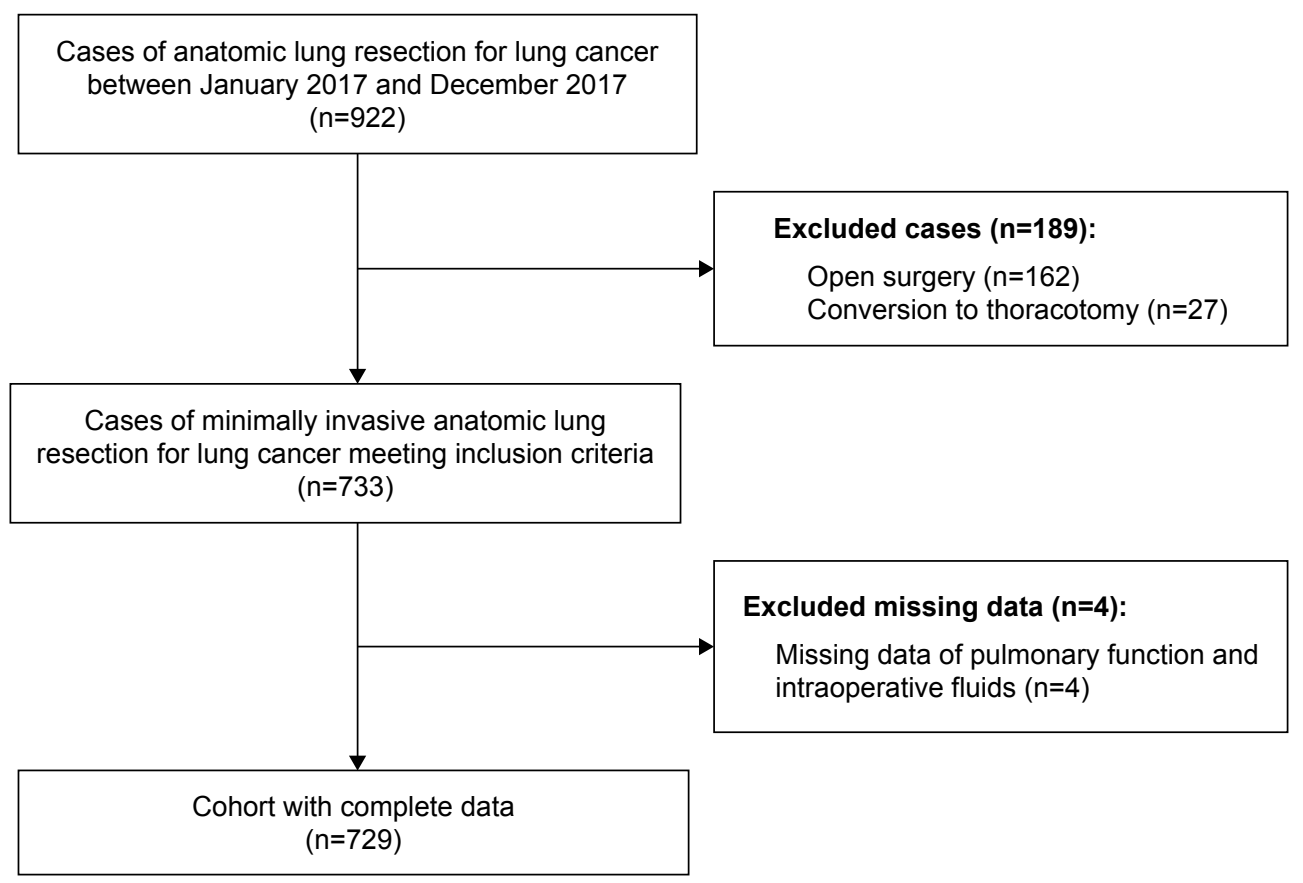

Figure I Flow diagram of the cohort selection. 
Table I Preoperative factors of patients with or without postoperative pulmonary complications by univariate analysis ( $\mathrm{n}=729$ )

\begin{tabular}{|c|c|c|c|c|}
\hline \multirow[t]{2}{*}{ Characteristics } & \multirow{2}{*}{$\begin{array}{l}\text { Entire cohort } \\
(n=729)\end{array}$} & \multicolumn{3}{|l|}{ Univariate analysis } \\
\hline & & $\begin{array}{l}\text { Postoperative } \\
\text { pulmonary } \\
\text { complications group } \\
(n=\mid 81)\end{array}$ & $\begin{array}{l}\text { No postoperative } \\
\text { pulmonary } \\
\text { complications group } \\
(n=548)\end{array}$ & $P$-value \\
\hline Age (years) & $57.9 \pm 8.5$ & $57.8 \pm 8.8$ & $58.0 \pm 8.4$ & 0.842 \\
\hline Gender (female/male) & $461 / 268$ & $116 / 65$ & $345 / 203$ & 0.784 \\
\hline Weight (kg) & $60.5 \pm 10.2$ & $61.1 \pm 10.6$ & $60.3 \pm 10.0$ & 0.317 \\
\hline Body mass index $\left(\mathrm{kg} / \mathrm{m}^{2}\right)$ & $22.9 \pm 3.0$ & $23.1 \pm 3.2$ & $22.8 \pm 2.9$ & 0.305 \\
\hline Body mass index grading & & & & 0.009 \\
\hline$<24.0 \mathrm{~kg} / \mathrm{m}^{2}$ & $485(66.5 \%)$ & $106(58.6 \%)$ & $379(69.2 \%)$ & \\
\hline$\geq 24.0 \mathrm{~kg} / \mathrm{m}^{2}$ & $244(33.5 \%)$ & 75 (4I.4\%) & $169(30.8 \%)$ & \\
\hline Smoking (pack-years) & $9.1 \pm 19.9$ & $9.6 \pm 18.6$ & $8.9 \pm 20.3$ & 0.702 \\
\hline Diabetes mellitus & $51(7.0 \%)$ & $11(6.1 \%)$ & $40(7.3 \%)$ & 0.576 \\
\hline Hypertension & $193(26.5 \%)$ & $44(24.3 \%)$ & $149(27.2 \%)$ & 0.446 \\
\hline Coronary heart disease & $10(1.4 \%)$ & $0(0.0 \%)$ & $10(1.8 \%)$ & 0.131 \\
\hline History of lung surgery or chest trauma & $17(2.3 \%)$ & $2(1.1 \%)$ & $15(2.7 \%)$ & 0.207 \\
\hline Preoperative renal insufficiency & $5(0.7 \%)$ & $2(1.1 \%)$ & $3(0.5 \%)$ & 0.602 \\
\hline $\mathrm{FEV}_{\text {, (percentage of predicted value) }}$ & $92.0 \% \pm 17.0 \%$ & $92.0 \% \pm 16.3 \%$ & $91.9 \% \pm 17.2 \%$ & 0.977 \\
\hline FVC (percentage of predicted value) & $92.3 \% \pm 15.5 \%$ & $91.4 \% \pm 15.3 \%$ & $92.6 \% \pm 15.5 \%$ & 0.368 \\
\hline $\begin{array}{l}\text { Peak expiratory flow (percentage of } \\
\text { predicted value) }\end{array}$ & $68.8 \% \pm 24.3 \%$ & $70.0 \% \pm 25.9 \%$ & $68.4 \% \pm 23.8 \%$ & 0.423 \\
\hline $\begin{array}{l}\text { American Society of Anesthesiologists } \\
\text { (ASA) physical status classification }\end{array}$ & & & & 0.750 \\
\hline ASA I & $366(50.2 \%)$ & $95(52.5 \%)$ & $27 \mid(49.5 \%)$ & \\
\hline ASA II & $348(47.7 \%)$ & $82(45.3 \%)$ & $266(48.5 \%)$ & \\
\hline ASA III & $15(2.1 \%)$ & $4(2.2 \%)$ & II (2.0\%) & \\
\hline Pathology & & & & 0.072 \\
\hline Adenocarcinoma, $\mathrm{n}$ & $665(91.2 \%)$ & $159(87.8 \%)$ & $506(92.3 \%)$ & \\
\hline Squamous cell carcinoma, $\mathrm{n}$ & $43(5.9 \%)$ & $14(7.7 \%)$ & $29(5.3 \%)$ & \\
\hline Adenosquamous carcinoma, $\mathrm{n}$ & $10(1.4 \%)$ & $2(1.1 \%)$ & $8(1.5 \%)$ & \\
\hline Small-cell lung cancer, $\mathrm{n}$ & II (I.5\%) & $6(3.3 \%)$ & $5(0.9 \%)$ & \\
\hline
\end{tabular}

Note: Values are presented as mean $\pm S D$, $n$, or $n(\%)$.

as described in Tables 1 and 2. According to the Health Industry Standard of China: Adult Weight Determination (WS/T428-2013), nutritional status is divided into four levels: underweight (BMI $<18.5 \mathrm{~kg} / \mathrm{m}^{2}$ ), normal weight $(18.5 \leq$ BMI $\left.<24.0 \mathrm{~kg} / \mathrm{m}^{2}\right)$, pre-obesity $\left(24.0 \leq\right.$ BMI $\left.<28.0 \mathrm{~kg} / \mathrm{m}^{2}\right)$, and obesity (BMI $\geq 28.0 \mathrm{~kg} / \mathrm{m}^{2}$ ). Therefore, we used BMI of $24 \mathrm{~kg} / \mathrm{m}^{2}$ as the boundary for BMI grading. Preoperative renal insufficiency was defined as creatinine $>50 \%$ the upper limit of the reference range, which is 1.3 and $1.1 \mathrm{mg} / \mathrm{dL}$ for men and women, respectively. ${ }^{7}$ The amount of total intraoperative fluids was defined as the volumes of crystalloid, colloid, and blood products administered between initiation of anesthesia care and arrival in the postanesthesia care unit. ${ }^{7}$ The colloid was hydroxyethyl starch. The net intraoperative total fluid was equal to the total intraoperative fluids minus intraoperative bleeding and urine output. Postoperative pathology of lung cancer included adenocarcinoma, squamous cell carcinoma, adenosquamous carcinoma, and small-cell lung cancer.

The PPCs included acute respiratory distress syndrome, reintubation, pneumonia, the need for bedside bronchoscopy, atelectasis, pulmonary embolism, prolonged air leak, and failure to expand during the period of postoperative hospitalization, as reported elsewhere. ${ }^{8}$ The three criteria used to diagnose postoperative pneumonia were a new pulmonary infiltrate on chest X-ray, leukocytosis, and fever (ear temperature $\geq 38.0^{\circ} \mathrm{C}$ ). ${ }^{8,9}$ Bedside bronchoscopy was used to clear lung secretions in the ward after the operation. Atelectasis was diagnosed by chest X-ray or computed tomography (CT), and pulmonary embolism was diagnosed 
Table 2 Intraoperative and postoperative factors of patients with or without postoperative pulmonary complications by univariate analysis $(n=729)$

\begin{tabular}{|c|c|c|c|c|}
\hline \multirow[t]{2}{*}{ Characteristics } & \multirow{2}{*}{$\begin{array}{l}\text { Entire cohort } \\
(n=729)\end{array}$} & \multicolumn{3}{|l|}{ Univariate analysis } \\
\hline & & $\begin{array}{l}\text { Postoperative pulmonary } \\
\text { complications group } \\
(\mathrm{n}=181)\end{array}$ & $\begin{array}{l}\text { No postoperative pulmonary } \\
\text { complications group } \\
(n=548)\end{array}$ & $P$-value \\
\hline Type of minimally invasive surgery & & & & 0.187 \\
\hline Video-assisted thoracoscopic surgery & $673(92.3 \%)$ & $163(90.1 \%)$ & $510(93.1 \%)$ & \\
\hline Robotic-assisted thoracoscopic surgery & $56(7.7 \%)$ & $18(9.9 \%)$ & $38(6.9 \%)$ & \\
\hline Type of anatomical lung resection & & & & 0.007 \\
\hline Single lobectomy & $654(89.7 \%)$ & $153(84.5 \%)$ & 501 (9I.4\%) & \\
\hline Single segmentectomy & $58(8.0 \%)$ & $19(10.5 \%)$ & $39(7.1 \%)$ & \\
\hline $\begin{array}{l}\text { Bilobectomy or combined } \\
\text { lobectomy and segmentectomy }\end{array}$ & $17(2.3 \%)$ & $9(5.0 \%)$ & $8(1.5 \%)$ & \\
\hline Surgical lobe & & & & 0.020 \\
\hline Left lung lobe & $283(38.8 \%)$ & $57(31.5 \%)$ & $226(41.2 \%)$ & \\
\hline Right lung lobe & $446(61.2 \%)$ & $124(68.5 \%)$ & $322(58.8 \%)$ & \\
\hline Intraoperative bleeding, $\mathrm{mL}$ & $47.2 \pm 32.5$ & $51.9 \pm 36.0$ & $45.6 \pm 31.2$ & 0.024 \\
\hline Intraoperative bleeding grading & & & & 0.027 \\
\hline$<50 \mathrm{~mL}$ & $290(39.8 \%)$ & 57 (3I.5\%) & $233(42.5 \%)$ & \\
\hline $50 \mathrm{~mL}$ to $<100 \mathrm{~mL}$ & $354(48.6 \%)$ & $98(54.1 \%)$ & $256(46.7 \%)$ & \\
\hline$\geq 100 \mathrm{~mL}$ & 85 (11.7\%) & $26(\mid 4.4 \%)$ & $59(10.8 \%)$ & \\
\hline Intraoperative urine output, $\mathrm{mL}$ & $391.2 \pm 318.4$ & $376.2 \pm 325.3$ & $396.1 \pm 316.3$ & 0.466 \\
\hline \multicolumn{5}{|l|}{ Amount of intraoperative fluids, $\mathrm{mL}$} \\
\hline Total & $1,527.0 \pm 412.8$ & I,479.0 \pm 395.0 & I,542.9 \pm 417.7 & 0.071 \\
\hline Crystalloid & $1,250.6 \pm 378.3$ & $\mathrm{I}, 222.1 \pm 357.4$ & $1,260.0 \pm 384.8$ & 0.242 \\
\hline Colloid & $276.4 \pm 258.3$ & $256.9 \pm 250.6$ & $282.8 \pm 260.6$ & 0.242 \\
\hline Blood & 0 & 0 & 0 & - \\
\hline $\begin{array}{l}\text { Amount of net intraoperative total } \\
\text { fluid, } \mathrm{mL}\end{array}$ & I,088.7 \pm 452.3 & $\mathrm{I}, 050.9 \pm 46 \mathrm{I} .0$ & I, $101.1 \pm 449.1$ & 0.195 \\
\hline Length of operation (minutes) & $|3| .2 \pm 35 . \mid$ & $133.4 \pm 35.5$ & $130.5 \pm 35.0$ & 0.330 \\
\hline Length of operation grading & & & & 0.169 \\
\hline$<90$ minutes & $86(11.8 \%)$ & $15(8.3 \%)$ & 71 (13.0\%) & \\
\hline 90 minutes to $<150$ minutes & $435(59.7 \%)$ & $108(59.7 \%)$ & $327(59.7 \%)$ & \\
\hline$\geq 150$ minutes & $208(28.5 \%)$ & $58(32.0 \%)$ & $150(27.4 \%)$ & \\
\hline Length of anesthesia (minutes) & $158.4 \pm 37.4$ & $162.4 \pm 38.3$ & $157.1 \pm 37.0$ & 0.098 \\
\hline Length of anesthesia grading & & & & 0.040 \\
\hline$<120$ minutes & $113(15.5 \%)$ & $23(12.7 \%)$ & $90(16.4 \%)$ & \\
\hline 120 minutes to $<180$ minutes & $418(57.3 \%)$ & $96(53.0 \%)$ & $322(58.8 \%)$ & \\
\hline$\geq 180$ minutes & $198(27.2 \%)$ & $62(34.3 \%)$ & $136(24.8 \%)$ & \\
\hline $\begin{array}{l}\text { Total intravenous crystalloid infusion in } \\
\text { the postoperative } 48 \text { hours, } \mathrm{mL}\end{array}$ & $2,459.8 \pm 569.1$ & $2,491.9 \pm 616.2$ & $2,449.2 \pm 552.8$ & 0.171 \\
\hline $\begin{array}{l}\text { Total intravenous colloid infusion in } \\
\text { the postoperative } 48 \text { hours, } \mathrm{mL}\end{array}$ & 0 & 0 & 0 & - \\
\hline
\end{tabular}

Note: Values are presented as mean $\pm S D, n$, or $n(\%)$.

by pulmonary artery CT angiography. A prolonged air leak was defined as leak $>7$ days. ${ }^{8}$ Failure to expand was accepted as the inability of the remaining lung to completely fill the pleural cavity with or without air leak, which was diagnosed by chest X-ray. ${ }^{8}$ The PLOS was defined as the number of hospitalized days after surgery. Hospital costs were the total hospital care costs. Among the 729 patients, 181 (24.8\%) had PPCs and were classified into a PPCs group. The remaining 
548 (75.2\%) patients without PPCs were classified into the no PPCs group.

\section{Statistical analysis}

Potential risk factors were detected using single-factor analysis. Continuous data were analyzed using one-way variance analysis. If the variance was not homogeneous, a nonparametric test (Kruskal-Wallis H-test for multiple independent samples) was used. Categorical variables were compared by the $R \times \mathrm{C}$ chi-squared test or Fisher's exact test, as appropriate. The potential risk factors with $P<0.05$ were further assigned, imported into the binary logistic regression equation, and analyzed. Table S1 shows the assignment of variables in binary logistic regression analysis. $P<0.05$ was considered statistically significant. The OR and $95 \%$ CI were calculated. All analyses were performed using SPSS 25.0 (SPSS, Inc., Chicago, IL, USA). ${ }^{7,10}$

\section{Results}

\section{Patient selection and clinical outcomes}

A total of 729 patients met our criteria for analysis (Figure 1). The incidence of PPCs was $24.8 \%(n=181)$. The four most common PPCs were pneumonia ( $\mathrm{n}=148,20.3 \%)$, failure to expand $(\mathrm{n}=22,3.0 \%)$, atelectasis $(\mathrm{n}=16,2.2 \%)$, and prolonged air leak ( $n=16,3.0 \%)$. No patient died during the period of hospitalization. The PLOS and total hospital care costs in the PPCs group were significantly higher than those in the no PPCs group (Table 3).

\section{Comparative univariate analysis of the potential risk factors of PPCs}

Univariate analysis was performed to determine the potential risk factors for PPCs after minimally invasive anatomic resection for lung cancer. Compared to the no PPCs group, the PPCs group demonstrated significant differences in BMI grading $(P=0.009)$, type of anatomical lung resection ( $P=0.007)$, surgical lobe $(P=0.020)$, intraoperative bleeding $(P=0.024)$, intraoperative bleeding grading $(P=0.027)$, and length of anesthesia grading $(P=0.040)$, while there were no discrepancies among the other variables (Tables 1 and 2).

\section{Binary logistic regression analysis of the risk factors of PPCs}

We included statistically significant factors in univariate analysis, namely, BMI grading, type of anatomical lung resection, surgical lobe, intraoperative bleeding grading, and length of anesthesia grading, in our binary logistic regression model, to evaluate the perioperative predictors of PPCs.

Table 3 Clinical outcomes of patients with or without postoperative pulmonary complications

\begin{tabular}{|c|c|c|c|c|}
\hline \multirow[t]{2}{*}{ Variables } & \multirow{2}{*}{$\begin{array}{l}\text { Entire cohort } \\
(n=729)\end{array}$} & \multicolumn{3}{|l|}{ Univariate analysis } \\
\hline & & $\begin{array}{l}\text { Postoperative pulmonary } \\
\text { complications group } \\
(n=\mid 8 I)\end{array}$ & $\begin{array}{l}\text { No postoperative pulmonary } \\
\text { complications group } \\
(n=548)\end{array}$ & $P$-value \\
\hline $\begin{array}{l}\text { Total number of pulmonary } \\
\text { complications, } \mathrm{n}\end{array}$ & 214 & 214 & 0 & - \\
\hline $\begin{array}{l}\text { Acute respiratory distress } \\
\text { syndrome, } n\end{array}$ & $3(0.4 \%)$ & $3(1.7 \%)$ & 0 & - \\
\hline Reintubation, $\mathrm{n}$ & $0(0.0 \%)$ & $0(0.0 \%)$ & 0 & - \\
\hline Atelectasis, $\mathrm{n}$ & $16(2.2 \%)$ & $16(8.8 \%)$ & 0 & - \\
\hline Pulmonary embolism, $\mathrm{n}$ & $2(0.3 \%)$ & $2(1.1 \%)$ & 0 & - \\
\hline $\begin{array}{l}\text { Need for bedside } \\
\text { bronchoscopy, } n\end{array}$ & $7(1.0 \%)$ & 7 (3.9\%) & 0 & - \\
\hline Pneumonia, $n$ & I 48 (20.3\%) & I 48 (8I.8\%) & 0 & - \\
\hline Prolonged air leak, $\mathrm{n}$ & $16(2.2 \%)$ & $16(8.8 \%)$ & 0 & - \\
\hline Failure to expand, $\mathrm{n}$ & $22(3.0 \%)$ & $22(12.2 \%)$ & 0 & - \\
\hline $\begin{array}{l}\text { Patients with pulmonary } \\
\text { complications, } \mathrm{n}\end{array}$ & I8I (24.8\%) & I8I (I00.0\%) & 0 & - \\
\hline In-hospital mortality, n & 0 & 0 & 0 & - \\
\hline $\begin{array}{l}\text { Postoperative length of } \\
\text { stay, days }\end{array}$ & $5.8 \pm 2.1$ & $7.0 \pm 3.1$ & $5.4 \pm I .4$ & 0.000 \\
\hline $\begin{array}{l}\text { Total hospital care costs } \\
\text { (RMB) }\end{array}$ & $61,642.5 \pm 13,897.5$ & $66,794.0 \pm 14,847.7$ & $59,941.0 \pm 13,146.2$ & 0.000 \\
\hline
\end{tabular}

Note: Values are presented as mean \pm SD, $n$, or $n(\%)$. 
Table 4 Logistic model of risk factors for postoperative pulmonary complications after minimally invasive anatomic resection for lung cancer

\begin{tabular}{|c|c|c|}
\hline Variables & $\begin{array}{l}\text { OR of postoperative pulmonary } \\
\text { complications }(95 \% \mathrm{Cl})\end{array}$ & $P$-value \\
\hline Body mass index grading $\left(\geq 24.0 \mathrm{~kg} / \mathrm{m}^{2} \mathrm{vs}<24.0 \mathrm{~kg} / \mathrm{m}^{2}\right)$ & $1.514(1.057-2.167)$ & 0.024 \\
\hline Type of anatomical lung resection & & 0.009 \\
\hline Single lobectomy & 1.000 & \\
\hline Single segmentectomy & $2.115(1.150-3.891)$ & 0.016 \\
\hline Bilobectomy or combined lobectomy and segmentectomy & $2.731(1.013-7.361)$ & 0.047 \\
\hline Surgical lobe (right lung lobe vs left lung lobe) & $1.519(1.046-2.205)$ & 0.028 \\
\hline Intraoperative bleeding grading & & 0.198 \\
\hline$<50 \mathrm{~mL}$ & 1.000 & \\
\hline $50 \mathrm{~mL}$ to $<100 \mathrm{~mL}$ & $1.430(0.966-2.117)$ & 0.074 \\
\hline$\geq 100 \mathrm{~mL}$ & $1.355(0.750-2.449)$ & 0.315 \\
\hline Length of anesthesia grading & & 0.156 \\
\hline$<120$ minutes & 1.000 & \\
\hline 120 minutes to $<180$ minutes & $1.177(0.695-1.995)$ & 0.544 \\
\hline$\geq 180$ minutes & $1.647(0.9 \mid 8-2.953)$ & 0.094 \\
\hline
\end{tabular}

Note: Results of binary logistics regression analysis are presented as adjusted $\mathrm{OR}, 95 \% \mathrm{Cl}$, and $P$-value.

Binary logistics regression analysis demonstrated that BMI grading $\left(\geq 24.0 \mathrm{~kg} / \mathrm{m}^{2} \mathrm{vs}<24.0 \mathrm{~kg} / \mathrm{m}^{2}\right.$ : OR $1.514,95 \%$ CI 1.057-2.167, $P=0.024)$, type of anatomical lung resection (single segmentectomy vs single lobectomy: OR $2.115,95 \%$ CI 1.150-3.891, $P=0.016$; bilobectomy or combined lobectomy and segmentectomy vs single lobectomy: OR 2.731, 95\% CI 1.013-7.361, $P=0.047$ ), and surgical lobe (right vs left lung lobe: OR $1.519,95 \%$ CI 1.046-2.205, $P=0.028$ ) were independent risk factors of PPCs after minimally invasive anatomic resection for lung cancer (Table 4).

\section{Discussion}

This study has shown a PPC frequency of $24.8 \%$ in lung cancer patients undergoing minimally invasive anatomic resection, which is still associated with significantly poor short-term outcomes, including increased PLOS and total hospital care costs (Table 3). No patient died during the period of hospitalization. Furthermore, four independent risk factors for PPCs after minimally invasive anatomic resection for lung cancer were identified: $\mathrm{BMI} \geq 24.0 \mathrm{~kg} / \mathrm{m}^{2}$, single segmentectomy, bilobectomy or combined lobectomy and segmentectomy, and right lung lobe surgery (Table 4).

The incidence of PPCs after lung resection varies. Agostini et $\mathrm{al}^{11}$ reported frequencies of $7.4 \%$, and Lugg et $\mathrm{al}^{6}$ documented a prevalence of $13.0 \%$, whereas Arslantas et al ${ }^{8}$ noted that PPCs occurred in $54.7 \%$ patients after lung resection. This fluctuation is due to the differences in the definition of PPCs. In the current study, PPCs were defined similarly to Arslantas et al, ${ }^{8}$ which included acute respiratory distress syndrome, reintubation, pneumonia, need for bedside bronchoscopy, atelectasis, pulmonary embolism, prolonged air leak, and failure to expand during the period of postoperative hospitalization. Our incidence of PPCs was $24.8 \%$, which was compatible with the reported frequency. ${ }^{1}$ In our series, the four most frequent complications were pneumonia (20.3\%), failure to expand (3.0\%), atelectasis $(2.2 \%)$, and prolonged air leak (3.0\%) (Table 3). No reintubation was identified in our series.

BMI is a well-known risk factor for PPCs. ${ }^{1}$ Being underweight or overweight has been shown to increase the risk of PPCs after lung resection. ${ }^{12}$ Our data demonstrated that the risk of PPCs in patients with BMI $\geq 24.0 \mathrm{~kg} / \mathrm{m}^{2}$ was higher than in patients with BMI $<24.0 \mathrm{~kg} / \mathrm{m}^{2}$ (OR 1.514, 95\% CI 1.057-2.167, $P=0.024$ ) (Table 4). Obese patients often have reduced lung volume, altered ventilation pattern, and comorbid conditions, which are risk factors for intraand postoperative complications. ${ }^{13,14}$ Being overweight is an important influencing factor on pre- and postoperative immune function. ${ }^{15}$ Additionally, an elevated BMI in patients will lead to increased difficulty during surgery and prolonged operative times. ${ }^{16}$ The prevalence of overweight and obesity is showing an upward trend. ${ }^{17}$ Thoracic surgeons will encounter more overweight and obese lung cancer patients in the future. Therefore, it was important to find whether BMI $\geq 24.0 \mathrm{~kg} / \mathrm{m}^{2}$ negatively impacts on outcomes after minimally invasive anatomic lung resection. Although a 
$\mathrm{BMI} \geq 24.0 \mathrm{~kg} / \mathrm{m}^{2}$ is not a contradiction for surgery, it should be considered when deciding to perform anatomic lung resection, given its strong association with PPCs.

Lobectomy has been the standard procedure for surgical treatment of non-small-cell lung cancer. In recent years, there has been growing evidence suggesting that segmentectomy can yield results equivalent to lobectomy in patients with early non-small-cell lung cancer. ${ }^{18}$ However, few reports have investigated postoperative complications exclusively in patients with lung cancer undergoing lobectomy or segmentectomy. In the present investigation, compared with single lobectomy, single segmentectomy and bilobectomy or combined lobectomy and segmentectomy were associated with an increased risk of PPCs (Table 4). Why is segmentectomy more prone to PPCs? Patients after segmentectomy had worse mean FEV1 than after lobectomy. ${ }^{19}$ When performing segmentectomy, surgeons have to divide the intersegmental plane using staplers or electrocautery, which may cause postoperative air leak and development of PPCs. ${ }^{18}$ Moreover, frequent clamping and pulling of the healthy lung tissue during segmentectomy would lead to postoperative pulmonary edema and development of PPCs. ${ }^{20}$ Unsurprisingly, bilobectomy or combined lobectomy and segmentectomy were associated with the development of PPCs because they produce greater trauma and more lung surface wound than single lobectomy.

Little information about the effects of lung surgery, performed on different lung lobes, on postoperative outcomes has been published to date. Our multivariate analysis revealed that patients undergoing right lung lobe surgery had an increased risk of PPCs (Table 4). The association is possibly related to the difference in lung volume between the left and right lung (ratio of right and left lung volume, 1.22 \pm 0.14 ), ${ }^{21}$ so the right lung lobe surgery has a greater impact on lung function, resulting in greater trauma and a higher risk of PPCs. In addition, because most of the bilobectomy or combined lobectomy and segmentectomy surgeries involved the right lung $(15 / 17)$, the surgery of the right lung lobe was associated with an increasing risk of PPCs.

\section{Limitations}

There were several limitations to this study. First, it was a single-center retrospective analysis, which may restrict the wide usage of our indications in clinics. A prospective multi-center study would be necessary to validate the risk factors of PPCs identified in our research and to define the best predictors of PPCs more rigorously. Second, numerous perioperative variables can lead to PPCs, but it is unlikely that all of these possible variables will be included in the study. Third, we only followed up our patients during their hospitalization. Hence, longitudinal studies are needed to evaluate the long-term clinical impacts of PPCs.

\section{Conclusion}

We identified several perioperative risk factors of PPCs following minimally invasive anatomic resection for lung cancer, including BMI $\geq 24.0 \mathrm{~kg} / \mathrm{m}^{2}$, single segmentectomy, bilobectomy or combined lobectomy and segmentectomy, and right lung lobe surgery. These results should be helpful for risk stratification, patient counseling, and perioperative care of lung cancer patients. Further studies are necessary to validate these findings and create a clinical scoring system to predict PPCs.

\section{Acknowledgments}

This research was funded by the Natural Science Foundation of Zhejiang Province (grant number LQ18H180002) and the National Natural Science Foundation of China (grant number 31700690). In addition, we appreciate the assistance of Large-scale Data Analysis Center of Cancer Precision Medicine-LinkDoc database for clinical and pathological data collected.

\section{Disclosure}

The authors report no conflicts of interest in this work.

\section{References}

1. Kim ES, Kim YT, Kang CH, et al. Prevalence of and risk factors for postoperative pulmonary complications after lung cancer surgery in patients with early-stage COPD. Int J Chron Obstruct Pulmon Dis. 2016; 11:1317-1326.

2. Howington JA, Blum MG, Chang AC, Balekian AA, Murthy SC. Treatment of stage I and II non-small cell lung cancer: diagnosis and management of lung cancer, 3rd ed: American College of chest physicians evidence-based clinical practice guidelines. Chest. 2013;143(5 Suppl): e278S-e313S.

3. Gupta H, Ramanan B, Gupta PK, et al. Impact of COPD on postoperative outcomes: results from a national database. Chest. 2013;143(6): 1599-1606.

4. Lugg ST, Agostini PJ, Tikka T, et al. Long-term impact of developing a postoperative pulmonary complication after lung surgery. Thorax. 2016; 71(2):171-176.

5. Sekine Y, Suzuki H, Yamada Y, Koh E, Yoshino I. Severity of chronic obstructive pulmonary disease and its relationship to lung cancer prognosis after surgical resection. Thorac Cardiovasc Surg. 2013;61(2):124-130.

6. Lugg ST, Tikka T, Agostini PJ, et al. Smoking and timing of cessation on postoperative pulmonary complications after curative-intent lung cancer surgery. J Cardiothorac Surg. 2017;12(1):52.

7. Shin CH, Long DR, Mclean D, et al. Effects of intraoperative fluid management on postoperative outcomes: a hospital registry study. Ann Surg. 2018;267(6):1084-1092.

8. Arslantas MK, Kara HV, Tuncer BB, et al. Effect of the amount of intraoperative fluid administration on postoperative pulmonary complications following anatomic lung resections. J Thorac Cardiovasc Surg. 2015; 149(1):314-321. 
9. Mommers EHH, Wegdam JA, van der Wolk S, Nienhuijs SW, de Vries Reilingh TS. Impact of hernia volume on pulmonary complications following complex hernia repair. J Surg Res. 2017;211:8-13.

10. van Lier F, van der Geest PJ, Hoeks SE, et al. Epidural analgesia is associated with improved health outcomes of surgical patients with chronic obstructive pulmonary disease. Anesthesiology. 2011;115(2):315-321.

11. Agostini PJ, Lugg ST, Adams K, et al. Risk factors and short-term outcomes of postoperative pulmonary complications after VATS lobectomy. J Cardiothorac Surg. 2018;13(1):28.

12. Ferguson $\mathrm{MK}$, Im HK, Watson $\mathrm{S}$, Johnson E, Wigfield $\mathrm{CH}$, Vigneswaran WT. Association of body mass index and outcomes after major lung resection. Eur J Cardiothorac Surg. 2014;45(4):e94-e99.

13. Suemitsu R, Takeo S, Hamatake M, Morokuma A, Suemori Y, Tanaka H. The results of surgery under general anesthesia in patients with lung cancer. Surg Today. 2011;41(1):60-66.

14. Xia L, Taylor BL, Guzzo TJ. Characteristics and associated factors of postoperative pulmonary complications in patients undergoing radical cystectomy for bladder cancer: a national surgical quality improvement Program Study. Clin Genitourin Cancer. 2017;15(6):661-669.

15. Lachmann G, von Haefen C, Kurth J, Yuerek F, Wernecke KD, Spies C. Smoking, gender, and overweight are important influencing factors on monocytic HLA-DR before and after major cancer surgery. Biomed Res Int. 2017;2017(5):1-7.
16. Salem AI, Thau MR, Strom TJ. Effect of body mass index on operative outcome after robotic-assisted Ivor-Lewis esophagectomy: retrospective analysis of 129 cases at a single high-tertiary care center. Dis Esophagus. 2017;30(1):1-7.

17. Wang C, Guo M, Zhang N, Wang G. Association of body mass index and outcomes following lobectomy for non-small-cell lung cancer. World J Surg Oncol. 2018;16(1):90.

18. Ohtsuka T, Kamiyama I, Asakura K, Kohno M. Thirty-day outcomes after lobectomy or segmentectomy for lung cancer surgery. Asian Cardiovasc Thorac Ann. 2015;23(7):828-831.

19. Shapiro M, Weiser TS, Wisnivesky JP, Chin C, Arustamyan M, Swanson SJ. Thoracoscopic segmentectomy compares favorably with thoracoscopic lobectomy for patients with small stage I lung cancer. J Thorac Cardiovasc Surg. 2009;137(6):1388-1393.

20. Hamada A, Oizumi H, Kato H, et al. Learning curve for port-access thoracoscopic anatomic lung segmentectomy. J Thorac Cardiovasc Surg. 2018;156(5):1995-2003.

21. Yu CG, Grant CA, Izatt MT, et al. Change in lung volume following thoracoscopic anterior spinal fusion surgery: a 3-dimensional computed tomography investigation. Spine. 2017;42(12):909-916. 


\section{Supplementary material}

Table SI Assignment of variables in binary logistics regression analysis

\begin{tabular}{|l|l|}
\hline Variables & Assignment instruction \\
\hline Body mass index grading & $\begin{array}{l}<24.0 \mathrm{~kg} / \mathrm{m}^{2}=\mathrm{I} \\
\geq 24.0 \mathrm{~kg} / \mathrm{m}^{2}=2\end{array}$ \\
\hline Type of anatomical lung resection & $\begin{array}{l}\text { Single lobectomy }=\mathrm{I} \\
\text { Single segmentectomy }=2 \\
\text { Bilobectomy or combined lobectomy and segmentectomy }=3\end{array}$ \\
\hline Surgical lobe & $\begin{array}{l}\text { Left lung lobe }=\mathrm{I} \\
\text { Right lung lobe }=2\end{array}$ \\
\hline Intraoperative bleeding grading & $<50 \mathrm{~mL}=\mathrm{I}$ \\
& $50 \mathrm{~mL}$ to $<100 \mathrm{~mL}=2$ \\
& $\geq 100 \mathrm{~mL}=3$ \\
\hline Length of anesthesia grading & $<120$ minutes $=1$ \\
& 120 minutes to $<180$ minutes $=2$ \\
& $\geq 180$ minutes $=3$ \\
\hline
\end{tabular}

\section{Publish your work in this journal}

Therapeutics and Clinical Risk Management is an international, peerreviewed journal of clinical therapeutics and risk management, focusing on concise rapid reporting of clinical studies in all therapeutic areas, outcomes, safety, and programs for the effective, safe, and sustained use of medicines. This journal is indexed on PubMed Central, CAS,
EMBase, Scopus and the Elsevier Bibliographic databases. The manuscript management system is completely online and includes a very quick and fair peer-review system, which is all easy to use. Visit http://www.dovepress.com/testimonials.php to read real quotes from published authors.

Submit your manuscript here: http://www.dovepress.com/therapeutics-and-clinical-risk-management-journal 